\title{
Short Communication: Turbidity as an Indicator of Escherichia coli Presence in Water Troughs on Cattle Farms
}

\author{
R. P. Smith, ${ }^{1}$ G. A. Paiba, and J. Ellis-Iversen \\ Veterinary Laboratories Agency, and Centre of Epidemiology and Risk Analysis, Woodham Lane, New Haw Addlestone, \\ Surrey KT15 3PB, United Kingdom
}

\begin{abstract}
Studies have shown that water-drinking troughs are an important source of Escherichia coli infection on cattle farms, and a study was designed to provide farmers with an easy-to-use tool to monitor trough contamination and help determine when to empty and clean water troughs. A total of 164 water troughs were sampled on 33 cattle farms, and the on-farm turbidity tester results were found to be significantly correlated with laboratory turbidity results. Turbidity was associated with $E$. coli concentration, although the association was not linear. Emptying the troughs within a week of sampling was shown to reduce the turbidity score, but no linear association between time of emptying and $E$. coli concentration was discovered. A turbidity score of 4 was set as a cutoff point for when to clean a trough, yielding a sensitivity of 0.94 and a specificity of 0.03 for identifying a level of $E$. coli concentration that was more likely to contain $E$. coli $\mathrm{O} 157$ (>5,800 cfu/100 mL).

Key words: Escherichia coli, drinking water, turbidity, England and Wales
\end{abstract}

Zoonotic pathogens such as verocytotoxic Escherichia coli O157 (VTEC O157) often result in asymptomatic infections in farm animals; thus, the farmer is often unaware of the presence of human pathogens in the stock. Simple methods of assessing the risk of exposure to such organisms would assist farmers in reducing the transmission among farm stock and may result in reducing the risk of onward transmission to people. Dirty drinking troughs may act as environmental reservoirs for VTEC O157 and other pathogens and allow recirculation of infection among animals. The presence of $E$. coli in dirty trough water has been associated with the presence of $E$. coli $\mathrm{O} 157$ in cattle, and $E$. coli $\mathrm{O} 157$ has been reported to persist for up to 8 mo in water trough sediment and still be infectious to calves after

Received August 9, 2007.

Accepted January 20, 2008.

${ }^{1}$ Corresponding author: r.smith@vla.defra.gsi.gov.uk
6 mo (Lejeune et al., 2001a,b; Ellis-Iversen et al., 2005). Lejeune et al. (2001b) showed that water troughs with $E$. coli 0157 present had significantly greater $E$. coli concentrations, and Rice and Johnson (2000) showed that the indicator wild-type $E$. coli was always present in troughs when the pathogenic strain E. coli $\mathrm{O} 157$ was also present.

Turbidity testing is generally used to estimate the suspension of $\mathrm{OM}$ in water by measuring the degree of light reflection caused by the suspended particles. Turbidity testing is used as an indicator of when to clean swimming pools, because high levels of turbidity can indicate high concentrations of bacteria and other $\mathrm{OM}$, which can reduce the effectiveness of disinfectants. In a recent study, turbidity was also found to be an indicator of Eimeria cyst concentration in water (EllisIversen et al., 2005).

This study aimed to develop and test a predictive tool that can be used by farmers to estimate the level of $E$. coli contamination of drinking trough water and thus to decide when to empty and clean such troughs. The objectives were 1) to investigate whether water turbidity can be used as a predictor for the presence of presumptive $E$. coli in water troughs; and 2) to assess the accuracy of an on-farm turbidity testing tool and recommend when a trough should be cleaned. Lejeune et al. (2001b) showed that troughs contaminated with E. coli $\mathrm{O} 157 \mathrm{had}$, on average, 1.76 E. coli $\left(\log _{10}\right) / \mathrm{mL}$, which equates to $5,800 \mathrm{cfu} / 100 \mathrm{~mL}$. This information was used to set a visual turbidity score (VTS) cutoff from which the trough is, on average, more likely to contain the $\mathrm{O} 157$ pathogenic strain of $E$. coli.

The data for this study were collected on 33 farms that had recently been tested and found to have at least one cow shedding VTEC 0157 in its feces, which was monitored as part of a different study (Ellis-Iversen et al., 2007). The farms represented most regions of England and Wales and were sampled between March 16 and June 7, 2004 (3 farms were sampled twice).

The on-farm turbidity tester consisted of a 1-L glass jug onto which an equally graduated test strip of increasing darkness was attached [marked from 1 (clear) to 10 (black)]. Each sample was collected by drawing 


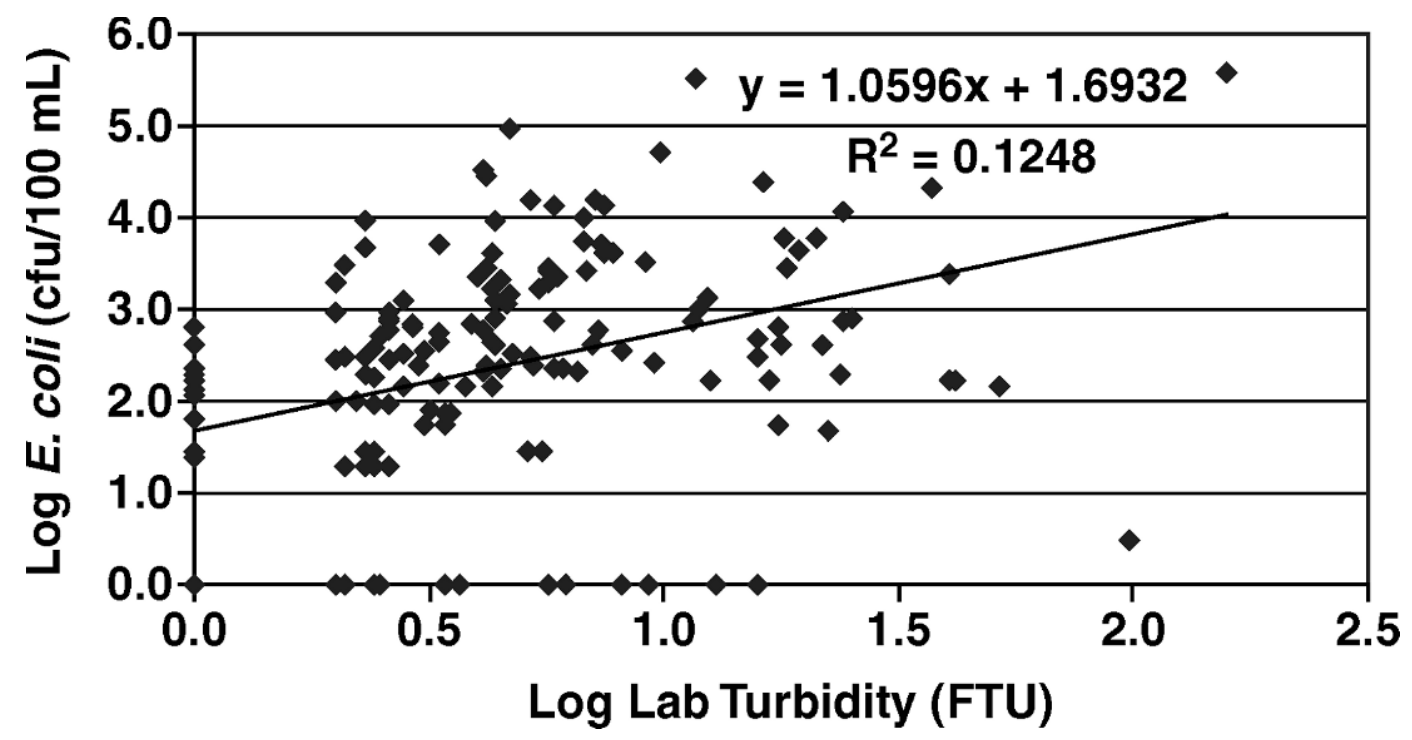

Figure 1. The relationship between water turbidity measured in a laboratory by spectrophotometry [fluorescent turbidity units (FTU)] and the concentration of Escherichia coli in the sample.

the bottle through the water in the trough, without stirring the water, and resuspending the sludge at the bottom of the trough. The VTS was scored as the lowest number visible when the jug was filled with water, and 5 readings were taken from different water troughs at each farm visit. The water samples were then sent to the National Laboratory Service in transport flasks containing $18 \mathrm{mg}$ of sodium thiosulfate, to counteract bacterial numbers being reduced by the possible presence of chlorine, and tested within $24 \mathrm{~h}$ of collection. A subsample of 100 to $150 \mathrm{~mL}$ was tested for turbidity and up to $1 \mathrm{~L}$ was tested for $E$. coli enumeration. Turbidity was measured by using a tungsten spectrophotometer (Environment Agency, 1981) and expressed as fluorescent turbidity units. Presumptive $E$. coli colonies were enumerated by membrane filtration and spread plating (Environment Agency, 2002) and reported as colonyforming units per $100 \mathrm{~mL}$, with a lower limit of detection of 10 colonies $/ 100 \mathrm{~mL}$.
Because some samples had a zero count, one was added to all counts to enable the log-conversion of all samples to reduce the effect of outliers. Visual turbidity score, laboratory turbidity, and bacterial concentrations were described by using Microsoft Excel scatter plots and compared by linear regression analysis clustered on farm and including visit month as an a priori confounder. The average VTS and enumeration results were also compared against individual water trough management practices (which were recorded on a sample collection form) by using either $t$-tests or Mood's median test. Geometric means were used to provide summaries of the skewed enumeration data. All analyses were completed by using STATA 9 (Stata Corp., College Station, TX) software.

A total of 164 water trough samples were collected from 36 farm visits [mean 4.6 samples per visit (min$\operatorname{imim} 2$, maximum 5)]. The linear regression model and the linear trend line showed that the turbidity of a

Table 1. Sensitivity and specificity scores for the effectiveness of an on-farm turbidity tester to detect concentrations of Escherichia coli linked to the presence of $E$. coli O157 in cattle water troughs

\begin{tabular}{|c|c|c|c|c|c|c|}
\hline \multirow[b]{2}{*}{ VTS $^{1}$} & \multicolumn{3}{|c|}{ E. $\operatorname{coli}>5,800 \mathrm{cfu} / 100 \mathrm{~mL}$} & \multirow{2}{*}{$\begin{array}{c}\text { VTS } \\
\text { comparison }\end{array}$} & \multirow[b]{2}{*}{ Sensitivity } & \multirow[b]{2}{*}{ Specificity } \\
\hline & Positive & Negative & Positive, $\%$ & & & \\
\hline 1 & 3 & 77 & 3.8 & 1 vs. $2-8$ & 0.17 & 0.46 \\
\hline 2 & 4 & 32 & 11.1 & $1-2$ vs. $3-8$ & 0.39 & 0.24 \\
\hline 3 & 4 & 25 & 13.8 & $1-3$ vs. $4-8$ & 0.61 & 0.06 \\
\hline 4 & 6 & 5 & 54.5 & $1-4$ vs. $5-8$ & 0.94 & 0.03 \\
\hline $5-8$ & 1 & 4 & 20.0 & & & \\
\hline
\end{tabular}

${ }^{1}$ Visual turbidity score. 


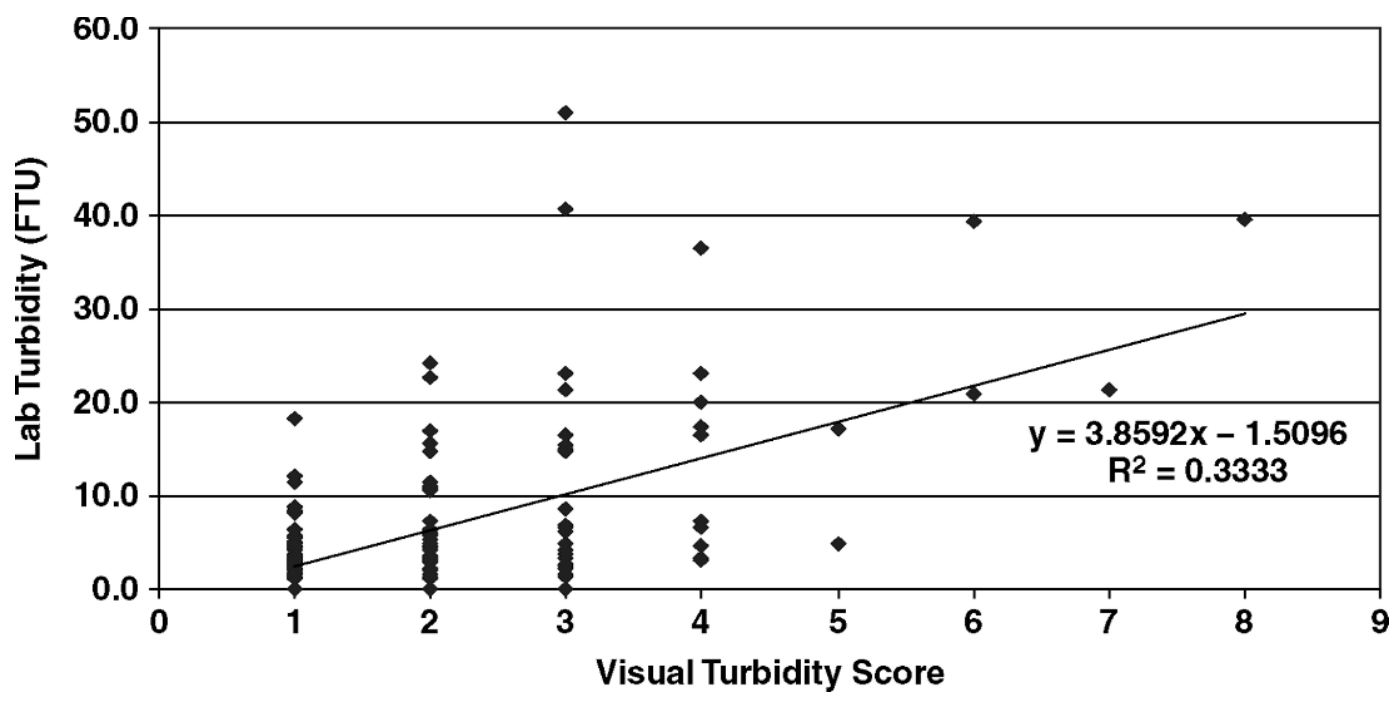

Figure 2. Relationship between laboratory turbidity scores [fluorescent turbidity units (FTU)] and the turbidity tester results (visual turbidity score, VTS) for water trough samples. One outlier was removed from the graph (VTS 3, laboratory turbidity 97 ).

water sample and the log-transformed concentration of presumptive $E$. coli were significantly associated $(P=$ 0.006), but the relationship was not linear and the coefficient of determination was low $\left(\mathrm{R}^{2}=0.124\right.$; Figure 1). The linear regression results of the VTS tool were strongly positively correlated with the turbidity measured in the laboratory $(P<0.001)$ and, although the linear coefficient of determination was low $\left(\mathrm{R}^{2}=0.333\right.$; Figure 2), it was considered a useful method of determining water turbidity.

The data were analyzed to identify a VTS cutoff point at which to empty and clean a water trough. Sensitivity and specificity were estimated for each increasing VTS score, against the remaining VTS, for whether more than $5,800 \mathrm{cfu} / 100 \mathrm{~mL}$ was detected (Table 1 ). The specificity of the test at all cutoffs was poor, but a comparison of VTS 1 to 4 against the others produced the highest sensitivity, and this was chosen as the cutoff because it was deemed more important to identify most samples with a substantial number of $E$. coli at the expense of false positive results. On average, $11 \%$ of samples with VTS 1 to 4 had concentrations of 5,800 or more $E$. coli cfu/100 mL, whereas VTS 5 to 8 had, on average, $20 \%$ of samples that were more likely to contain E. coli O157, as indicated by the research of Lejeune et al. (2001b).

The majority $(72.3 \%)$ of water troughs used water from water mains (public water supply) and almost all (92.8\%) were in current use. Troughs in current use had a significantly higher presumptive $E$. coli count than those not in use (Table 2). Water from water mains had, as expected, lower turbidity scores, but the geometric means showed a significantly higher average $E$. coli count than water not from water mains $(P<0.001)$.
The crude results indicate that water not from water mains had fewer positive samples but with larger $E$. coli counts. The use of water not from water mains is frequently supplemented by adding disinfectants posttapping (Rutter et al., 2000). The large variation between $E$. coli counts could have been caused by inactivation of disinfectants by OM, UV light, or other factors in some of the troughs and by effective disinfection in the others.

Just over half (54.1\%) of all troughs had been emptied in the week before a visit, and $25.7 \%$ had not been emptied in the last $3 \mathrm{wk}$. An analysis of these emptied troughs indicated that emptying the water trough within a week before sampling reduced the VTS but had no linear effect on $E$. coli counts, which may indicate that, although the troughs are regularly contaminated by $E$. coli, other turbidity elements are reduced when the water is refreshed. Straw was present in $36.6 \%$ of troughs, and $26.8 \%$ contained noticeable sediment or debris, but neither had an apparent effect on the turbidity, although $E$. coli counts increased with visible contamination. The $9.8 \%$ of troughs with algae or scum present had significantly higher VTS scores, and none of these troughs had been emptied in the week before the sampling visit.

The standing water in water troughs is often suspected as an on-farm source of microorganism recycling among groups of cattle, and pathogens such as VTEC O157, Campylobacter, Cryptosporidium, Giardia lambda, and Eimeria have all been associated with and isolated from water (Slifko et al., 2000; Lejeune et al., 2001a,b; Nygard et al., 2004; Ellis-Iversen et al., 2005). Although the VTS tool did not accurately predict $E$. coli 
Table 2. Water trough sample results presented against individual water hygiene practices

\begin{tabular}{|c|c|c|c|c|c|}
\hline Factor & $\begin{array}{l}\mathrm{VTS},{ }^{1} \\
\text { median }\end{array}$ & $\begin{array}{c}P \text {-value, } \\
\text { Mood's test }\end{array}$ & $\begin{array}{c}\text { Presumptive } \\
\text { Escherichia coli, } \\
\text { geometric } \\
\text { mean } / 100 \mathrm{~mL}\end{array}$ & $\begin{array}{c}P \text {-value } \\
t \text {-test }\end{array}$ & $\underset{\mathrm{n}}{\text { Troughs, }}{ }^{2}$ \\
\hline Water main & & 0.130 & & $<0.001$ & 155 \\
\hline Yes & 1.0 & & 315 & & \\
\hline No & 2.0 & & 126 & & \\
\hline In use & & 0.842 & & $<0.001$ & 152 \\
\hline Yes & 2.0 & & 296 & & \\
\hline No & 2.0 & & 29 & & \\
\hline Straw present & & 0.884 & & $<0.001$ & 164 \\
\hline Yes & 2.0 & & 348 & & \\
\hline No & 2.0 & & 202 & & \\
\hline Sediment present & & 0.229 & & $<0.001$ & 164 \\
\hline Yes & 1.0 & & 360 & & \\
\hline No & 2.0 & & 214 & & \\
\hline Algae or scum present & & 0.011 & & 0.005 & 164 \\
\hline Yes & 2.5 & & 233 & & \\
\hline No & 1.0 & & 248 & & \\
\hline Trough emptied & & 0.004 & & $<0.001^{3}$ & 75 \\
\hline Last week & 1.0 & & 270 & & \\
\hline $1-3 \mathrm{wk}$ & 1.0 & & 105 & & \\
\hline$>3 \mathrm{wk}$ & 2.0 & & 190 & & \\
\hline
\end{tabular}

${ }^{1} \mathrm{VTS}=$ visual turbidity score.

${ }^{2}$ The VTS analysis excluded 1 sample and $E$. coli excluded 2 samples because of missing results.

${ }^{3}$ ANOVA test used.

concentrations, the VTS had a strong positive relationship with the laboratory turbidity test score. Recommending to farmers that water troughs be emptied and cleaned when the VTS is greater than 4 may help to reduce concentrations of $E$. coli linked to the presence of $E$. coli $\mathrm{O} 157$ and might also reduce the presence of other pathogens in water.

Emptying and cleaning water troughs is a laborious task for farmers, and an on-farm VTS tool could aid them in deciding when to empty a water trough. However, to achieve a high probability of emptying troughs likely to contain a high level of $E$. coli, many troughs that do not contain this level of $E$. coli would also be emptied. The association between VTS and other pathogens needs investigation.

\section{ACKNOWLEDGMENTS}

The authors would like to thank the National Laboratory Service (Stacross, UK) for examining the samples, the Veterinary Laboratories Agency Regional Laboratory staff who carried out the sampling visits, and the farmers who participated in the study. The work was funded by Defra (London, UK) through projects OZ0138 and OZ0145.

\section{REFERENCES}

Ellis-Iversen, J., G. Paiba, and R. Smith. 2005. A longitudinal study of faecal excretion of VTEC O157 in cattle to determine epidemio- logical patterns and risk factors associated with excretion. Defra Project OZ0138. http://www.defra.gov.uk/science/project_data/ DocumentLibrary/OZ0138C/OZ0138C_3750_FRP.doc Accessed Nov. 14, 2007.

Ellis-Iversen, J., R. P. Smith, L. C. Snow, E. Watson, M. Millar, G. C. Pritchard, A. R. Sayers, A. J. C. Cook, S. J. Evans, and G. A. Paiba. 2007. Identification of management risk factors for VTEC O157 on cattle farms in England and Wales. Prev. Vet. Med. 82:29-41.

Environment Agency. 1981. Methods for the Examination of Water and Associated Materials. Colour and Turbidity of Waters. Environment Agency, Reading, UK.

Environment Agency. 2002. The microbiology of drinking water (2002) - Part 4-Methods for the isolation and enumeration of coliform bacteria and Escherichia coli (including E. coli $\mathrm{O} 157: \mathrm{H} 7$ ). http://www.environment-agency.gov.uk/commondata/acrobat/ mdwpart4.pdf Accessed 9th November 2007.

Lejeune, J. T., T. E. Besser, and D. D. Hancock. 2001a. Cattle water troughs as reservoirs of Escherichia coli O157. Appl. Environ. Microbiol. 67:3053-3057.

Lejeune, J. T., T. E. Besser, N. L. Merrill, D. H. Rice, and D. D. Hancock. 2001b. Livestock drinking water microbiology and the factors influencing the quality of drinking water offered to cattle. J. Dairy Sci. 84:1856-1862.

Nygard, K., Y. Andersson, J. A. Rottingen, A. Svensson, J. Lindback, T. Kistemann, and J. Giesecke. 2004. Association between environmental risk factors and campylobacter infections in Sweden. Epidemiol. Infect. 132:317-325.

Rice, E. W., and C. H. Johnson. 2000. Short communication: Survival of Escherichia coli O157:H7 in dairy cattle drinking water. J. Dairy Sci. 83:2021-2023.

Rutter, M., G. L. Nichols, A. Swan, and J. De Louvois. 2000. A survey of the microbiological quality of private water supplies in England. Epidemiol. Infect. 124:417-425.

Slifko, T. R., H. V. Smith, and J. B. Rose. 2000. Emerging parasite zoonoses associated with water and food. Int. J. Parasitol. 30:1379-1393. 